\title{
Study of Some Mistakes from the Students in Calculus Course at Mathematics Department FMIPA Universitas Negeri Padang
}

\author{
$1^{\text {st }}$ Dewi Murni \\ Department of Mathematics \\ Universitas Negeri Padang \\ Padang, Indonesia \\ dewimunp@gmail.com
}

\begin{abstract}
In Calculus the majority of students have not mastered the material well. To make improvements to the mastery of students it is necessary to analyze the mistakes that they do a lot. The purpose of this study is to find out the materials that are difficult to understand and the form of mistakes that many of them do. This research is descriptive research with research instrument is test result of the study and questionnaire. Data analysis performed consisted of three stages: transcript stage, classification stage, and data deduction phase. From the results of the research, it is found that the material that is difficult to master is to make a mathematical model of the story problem, describing some special graphs. Mistakes are done many times in a row: mistakes in principles, concepts, and skills.
\end{abstract}

Keywords—concepts, facts, mistake, principles, skills

\section{INTRODUCTION}

Calculus is the basic course for all students majoring in Mathematics given in the first semester. This course provides the knowledge base for the next course so that the mastery of the calculus material will greatly affect the subsequent mastery of the material. It is, therefore, necessary to have excellent mastery by the students, but in reality, most of the students' values are still not satisfactory $(\mathrm{C}, \mathrm{D}$, and $\mathrm{E})$. This low student mastery indicates that students have difficulty in understanding Calculus material. As stated by Djamarah (2008): "One symptom as an indicator of learning difficulties is that students show low learning outcomes, below the average scores achieved by other groups of students in the classroom. Likewise, what happens in other countries Students also experience difficulties in calculus courses such as those put forward [3]. The analysis of the results from the tests showed that a majority of the errors were due to knowledge gaps in basic algebra. We also noted that errors and misconceptions in calculus were related to learners' lack of advanced mathematical thinking since concepts in calculus are intertwined.

Furthermore, according to Mulyadi (2010), learning difficulties is a condition in a learning process that is marked by certain barriers to achieving learning outcomes (Mulyadi, 2010). Learning difficulties are a situation where students can not learn properly. Meanwhile, according to Jamaris (2013). Learning difficulties can also be interpreted as an abnormality that makes the individual concerned difficult to perform learning activities effectively.
The difficulties experienced by the students caused many students to make mistakes in solving calculus problems. It is, therefore, necessary to examine carefully which materials are elusive students and what are some forms of mistakes that many students do. Mathematics especially calculus contains four objects, namely: facts, concepts, principles, and skills. If students make mistakes then at least one of these four objects must not have mastered the students. Based on the background of the problem, then the formulation of this research problem is: 1) On which material in the course Calculus mistakes many students do, 2) How the form of student error on mathematical objects: facts, concepts, principles, and skills

The Calculus course which weighs 4 credits is the basic course for all students of the Mathematics Department, which contains material: inequality, function, derivative and its application, integral and its application. In understanding and mastering Calculus material then the student must master the four objects of mathematics that exist in the Calculus course are facts, concepts, principles, and skills. According to Bayu Prasetyo, 2016:

Facts are all deal in mathematics, like mathematical symbols. Students are said to understand the facts when they have been able to name and use them appropriately. In mathematics, facts are something that must be taken for granted because it is just a semufakatan. For example, it is a fact (the haruis is taken for granted) that the emblem for the indefinite integral is

$$
\int \ldots d x
$$

The concept is an abstract idea that allows one to determine whether an object or event is an example or not an example of a concept. Learning materials of concept type is a matter of definition or understanding. The purpose of studying the concept is that learners can understand, can show the characteristics, elements, differentiate, compare, generalize, etc. Students are said to master the concept if they are able to identify examples and non-examples of concepts. The concept example is the definition of a continuous function at a point $\mathrm{c}$ that is if.

$$
\lim _{x \rightarrow c} f(x)=f(c)
$$

The principle is a series of several concepts together and relationships (interrelations) between these concepts. Students are said to master the principle if they can identify 
the concepts embodied in the principle, define interconnected relationships, and apply those principles to specific situations. Including learning materials of principle, the type is proposition, formula, law (law), postulate, theorem, etc..

An example concept is the definition of a continuous function at a point $\mathrm{c}$ that is if.

$$
\lim _{x \rightarrow c} f(x)=f(c)
$$

Skills are operations or procedures that students are expected to master quickly and appropriately. The purpose of studying the procedure is so that learners can perform or practice the procedure, not just understand or memorized. Including learning materials of the type of procedure is the steps to perform a task in sequence. The student is said to master the skill if he can demonstrate the skill properly, be able to solve the various problems that require the skill and apply the skill to various situations. An example of a mathematical skill in the process of finding the sum of two numbers, the process of finding the smallest multiple of the two numbers and so on.

In this study, the errors observed are material kesaahan and formal mistakes, as proposed Wayan Nurkancana, 1993, states "material error means the classification based on the subject matter materials. While the formal error means the classification based on the knowledge of the lesson." Material error is the error obtained in parts of the research material, while the formal error is a mistake in the use of mathematical objects that are errors in using facts, concepts, principles, and skills (skill). In this study, the student is considered still not mastered the material Calculus is the value still $\mathrm{C}, \mathrm{D}$, and $\mathrm{E}$ that is less than 65 (in standard 100). Appropriate academic rules of Universitas Negeri Padang.

\section{RESEARCH METHODS}

In accordance with the purpose of research, this research is descriptive research, which describes the mistakes made by students in solving calculus problems. The subject of the research is a class of students majoring in Mathematics who take the calculus of the academic year 2016/2017. The research instrument is a written test in the form of descriptions (essays) and questionnaires. Provision of a description test is intended to see what mistakes the student made while the questionnaire to reveal the cause of the mistakes. Data analysis was done in three stages: transcript stage, classification stage and data deduction stage.

\section{DISCUSSION}

To find out the mistakes of students in completing the calculus so done three tests. The first, Student test results are grouped into good values $(>=65)$ and unfavorable $(<65)$. According to the rules The results of the first test can be seen in the following table:

TABLE I. Distribution of STUdents Who Scored AbOve AND BELOW 65 ON THE FIRST TEST

\begin{tabular}{|l|l|c|c|}
\hline $\begin{array}{c}\text { The Subject } \\
\text { Matter Being Tested }\end{array}$ & \multicolumn{1}{|c|}{$\begin{array}{c}\text { Problem } \\
\text { Number }\end{array}$} & $\begin{array}{l}\text { Score >= 65 } \\
(\mathbf{\%})\end{array}$ & $\begin{array}{c}\text { Score < 65 } \\
(\mathbf{\%})\end{array}$ \\
\hline Inequality & Problem 1 & 82 & 18 \\
\hline Absolute Inequality & Problem 2 & 41 & 59 \\
\hline $\begin{array}{l}\text { Sketch a function } \\
\text { graph }\end{array}$ & Problem 3, 4 & 32 & 68 \\
\hline Limit function & Problem 5a, 5b & 36 & 64 \\
\hline Function Continuity & Problem 4 & 23 & 77 \\
\hline
\end{tabular}

From table 1 it is known that the most material has not been mastered by students is sketching the graph especially special function graph and function many rules.

Furthermore, from the error in calculus material, an error analysis of four mathematical objects is performed, with the result shown in table 2.

TABLE II. THE NUMBER OF STUDENTS WHO MADE A FORMAL MISTAKE ON THE FIRST TEST

\begin{tabular}{|l|c|c|c|c|}
\hline \multirow{2}{*}{$\begin{array}{c}\text { Problem } \\
\text { Number }\end{array}$} & \multicolumn{4}{|c|}{ Jenis Kesalahan } \\
\cline { 2 - 5 } & Facts & Concept & Principle & Skills \\
\hline Problem 1 & - & 14 & 18 & 23 \\
\hline Problem 2 & - & 32 & 27 & 27 \\
\hline Problem 3, 4 & 27 & 59 & 68 & 45 \\
\hline $\begin{array}{l}\text { Problem } \\
\text { 5a,5b }\end{array}$ & - & 23 & 36 & - \\
\hline Problem 4 & - & 18 & 27 & 10 \\
\hline
\end{tabular}

From an analysis of formal mistake it is known:

The mistake of fact: among other things, mistakes in drawing/sketching function curves, facts concave upwards, concave down, as well as on special function sketches. The principal mistakes are made such as the principle of drawing linear equations and quadratic equations. Such concept errors apply the concept of the largest integer function into the image. While the general skill mistake in opening the curly brackets is often a sign of positive and negative numbers being wrong so also less thorough in laying the coordinate point.

The mistake in opening the curly brackets is often a sign of positive and negative numbers being wrong so also less thorough in laying the coordinate point.

TABLE III. DISTRIBUTION NUMBER OF STUDENTS WHO SCORED ABOVE AND BELOW 65 ON THE SECOND TEST

\begin{tabular}{|l|l|c|c|}
\hline $\begin{array}{c}\text { The Subject Matter } \\
\text { Being Tested }\end{array}$ & \multicolumn{1}{|c|}{$\begin{array}{c}\text { Problem } \\
\text { Number }\end{array}$} & $\begin{array}{c}\text { Score }>= \\
\mathbf{6 5} \\
\mathbf{( \% )}\end{array}$ & $\begin{array}{c}\text { Score } \\
\mathbf{6 5} \\
\mathbf{( \% )}\end{array}$ \\
\hline Finding Derivatives & Problem 1a, 1b & 77 & 23 \\
\hline Implicit differentiation & Problem, 2b & 64 & 36 \\
\hline Related Rates & Problem 3, & 23 & 77 \\
\hline Maxima and Minima & Problem 5 & 27 & 73 \\
\hline Graphing Functions & Probleml 4 & 36 & 64 \\
\hline
\end{tabular}

From table 3, it can be seen that the most material has not been mastered by students is solve the problem of derivative application that is about the related rate and the problem of maximum and minimum.

Furthermore, the error in Calculus material is done an analysis of four mathematical objects.

TABLE IV. Distribution OF STUDENTS Who MADE FormaL MistaKes ON THE SECOND TEST

\begin{tabular}{|c|c|c|c|c|}
\hline \multirow{2}{*}{$\begin{array}{c}\text { Problem } \\
\text { Number }\end{array}$} & \multicolumn{4}{|c|}{ The Type of Mistakes ( \% ) } \\
\cline { 2 - 5 } & Facts & Concept & Principle & Skill \\
\hline Problem 1a, 1b & - & 10 & 23 & 14 \\
\hline $\begin{array}{c}\text { Probleml 2a, } \\
\text { 2b }\end{array}$ & - & 14 & 32 & 32 \\
\hline Problem 3, & 23 & 10 & 68 & 23 \\
\hline Probleml 5 & - & 18 & 77 & 73 \\
\hline Probleml 4 & - & 10 & 73 & 36 \\
\hline
\end{tabular}


From table 4, it can be seen that in the second test of mistake that many students do is a principle mistake that students have not been accustomed to linking derivative concepts with derivative use in solving derivative application problems, namely those related to rate problems, maximum problems, minimum problems, and drawing graphs, function.

TABLE V. Distribution OF STUdENTS Who SCORED ABOvE AND BELOW 65 ON THE THIRD TEST

\begin{tabular}{|l|c|c|c|}
\hline $\begin{array}{l}\text { The Subject Matter } \\
\text { Being Tested }\end{array}$ & $\begin{array}{c}\text { Problem } \\
\text { Number }\end{array}$ & $\begin{array}{c}\text { Score >= 65 } \\
(\mathbf{\%})\end{array}$ & $\begin{array}{c}\text { Score < 65 } \\
(\%)\end{array}$ \\
\hline Definite integrals & $1 \mathrm{a}, 1 \mathrm{~b}, 1 \mathrm{c}$ & 77 & 23 \\
\hline Undefinite integrals & $2 \mathrm{a}, 2 \mathrm{~b}, 2 \mathrm{c}$ & 68 & 32 \\
\hline $\begin{array}{l}\text { Trigonometric } \\
\text { Integrals }\end{array}$ & $3 \mathrm{c}$ & 28 & 82 \\
\hline $\begin{array}{l}\text { Rationalizing } \\
\text { substitutions }\end{array}$ & $3 \mathrm{~d}$ & 32 & 68 \\
\hline \begin{tabular}{l} 
Integration by parts \\
\multicolumn{1}{|c|}{ of }
\end{tabular} & $3 \mathrm{a}, 3 \mathrm{~b}$ & 41 & 59 \\
\hline $\begin{array}{l}\text { Integration } \\
\text { Rational functions }\end{array}$ & 4 & 36 & 64 \\
\hline $\begin{array}{l}\text { Applications of the } \\
\text { Integrals }\end{array}$ & & 36 & 59 \\
\hline
\end{tabular}

In the third test, the material that is less controlled by students is integral material trigonometric functions and rationalizing substitutions. Furthermore, the error in Calculus material is done an analysis of four mathematical objects, as in table 6 .

TABLE VI. Distribution OF STUDENTS WHO MADE FORMAL MISTAKES ON THE THIRD TEST

\begin{tabular}{|l|c|c|c|c|}
\hline \multirow{2}{*}{$\begin{array}{l}\text { Problem } \\
\text { Number }\end{array}$} & \multicolumn{4}{|c|}{ The Type of Mistakes ( \% ) } \\
\cline { 2 - 5 } & Facts & Concept & $\begin{array}{c}\text { Princ } \\
\text { iple }\end{array}$ & Skill \\
\hline $\begin{array}{l}\text { Problem } \\
\text { 1a,1b,1c }\end{array}$ & 18 & 10 & 23 & 10 \\
\hline $\begin{array}{l}\text { Problem } \\
\text { 2a,2b,2c }\end{array}$ & 10 & 14 & 36 & - \\
\hline Problem 3c & - & 45 & 82 & 14 \\
\hline Problem 3d & - & 64 & 64 & 10 \\
\hline $\begin{array}{l}\text { Problem } \\
\text { 3a,3b }\end{array}$ & - & 45 & 45 & 10 \\
\hline Problem 3e & - & 36 & 45 & 18 \\
\hline Problem 4 & - & 23 & 55 & 23 \\
\hline
\end{tabular}

In general, the errors that many students do in the Calculus course as follows:

In the first test, the material most widely considered difficult by students is to determine the point of function continuity at a point. Hereinafter respectively: muskets graph function, determine the limit of special functions, and absolute inequalities.

In the second test, the most difficult material for students to understand is in the matter of derived applications on the related rate problem, where the students have not been able to change the story into mathematical equations. Further in succession: in the application material the maximum and minimum problems, the same error also when modeling from story to mathematical equations, then errors when drawing sophisticated graphics, not thorough in sketching according to existing theory.

In the third test, the most elusive material of the students is on the integrals of advanced trigonometric functions, in which the students do not understand each concept so they often misunderstand the concept. Hereafter respectively: determines the partial integrals, integrates the rational function.

As for the formal mistakes that many students make are conceptual errors and principle errors in the integral and partial integral material. To complete information about the material that is difficult for students to understand, the researchers distributed mixed questionnaires (closed and open). Distribution of the number of students who find it difficult to understand calculus material.

In the first most material test (as many as 12 people $(55 \%))$ considered difficult by students is to determine the continuity point of the function at a point. Furthermore, successively: sketching the function graph of 9 people $(39 \%)$ determines the limit of the special functions of 7 people $(30 \%)$, and the absolute inequality is 4 people $(17 \%)$.

In the second test, the material is the most difficult for students to understand is the application problem derived from the related rate problem, where students have not been able to change the story problem into 16 mathematical equations $(70 \%)$. Furthermore, in a row: the maximum and minimum problems in the application material, the same mistake when modeling from story to math equation 15 people $(65 \%)$, then an error when drawing sophisticated graphics, not careful in sketching according to the existing theory.

In the third test, the material that is most difficult for students to understand is integral to advanced trigonometric functions, where students do not understand each concept so that they are often wrong in using the concept of 16 people (70\%). Furthermore, successively: determine partial integral (15 people $(65 \%)$, integrate rational functions (11 people (48\%).

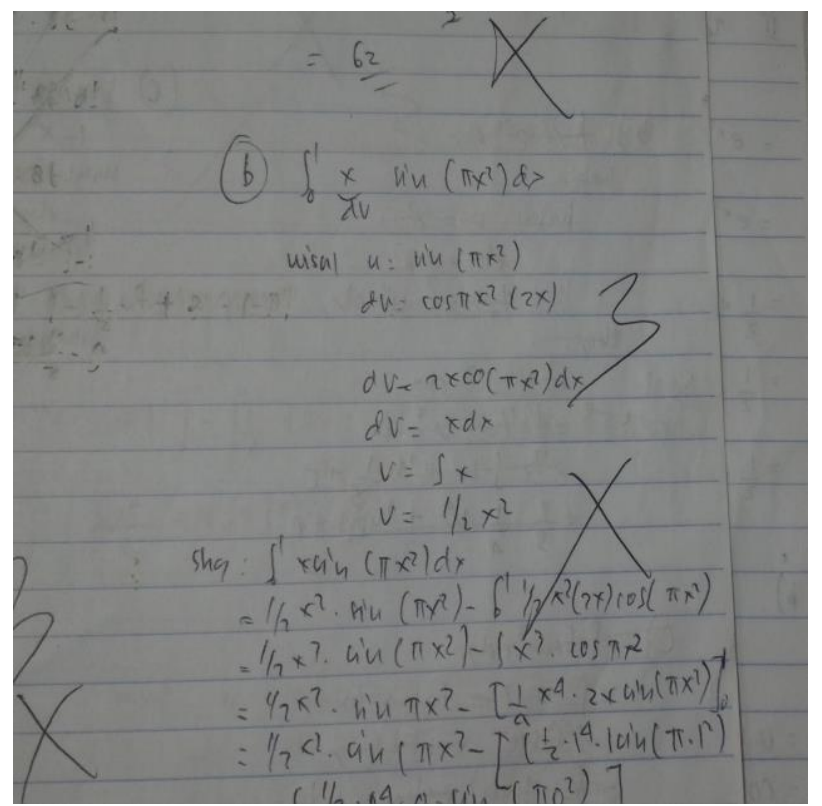

Fig.1. . The example of students' mistake on the fact that is about the use of derivative and integral symbols, and the mistake on principle. 


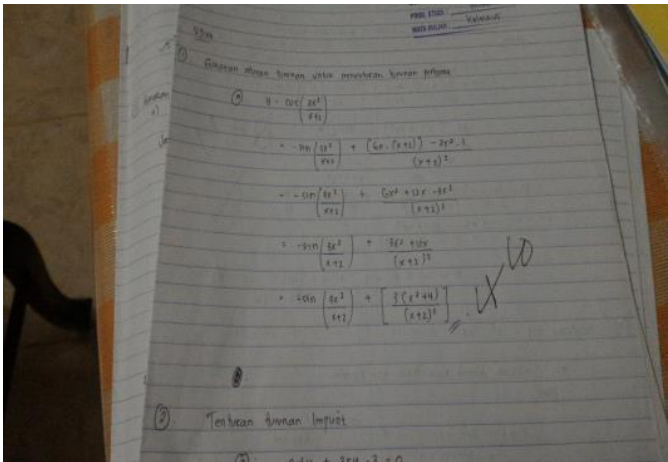

Fig.2. . The example of a students' mistake on the skill that is not thorough in use multiplication to multiplication

\section{CONCLUSION}

1. The materials which are misaligned by students are Sketch the graph of the function, Function Continuity, Related Rates Maxima and Minima, Trigonometric Integrals Rationalizing substitutions.

2. The formal mistakes that students do in succession are on principles, concepts, skills, and facts

\section{REFERENCES}

[1] Djamarah. Syaiful Bahri, Psikologi Belajar, Jakarta: Rineka Cipta, 2008.

[2] Jamaris. Martini, Orientasi Baru dalam Psikologi Pendidikan, Bogor: Ghalia Indonesia, 2013.

[3] Muzangwa. Jonatan, Chifamba. Peter, "Analysis of Errors and Misconceptions in the Learning of Calculus by Undergraduate Students, Babes-Bolyai University", Kogainiceanu 1, Cluj-Napoca, 400084 Romania. e-mail: submit_adn@yahoo.com; Website: http://adn.teaching.ro, Publication Type: Journal Articles, 2012.

[4] Mulyadi. H, Diagnosis Kesulitan Belajar dan Bimbingan Terhadap Kesulitan Belajar Khusus, Yogjakarta: Nuha Litera, 2010.

[5] Nurkancana Wayan, Evaluasi Pendidikan, Surabaya: Usaha Nasional, 1993.

[6] Prasetyo Bayu, Fakta-Konsep-Prinsip dan Keterampilan, Antasena 13, 2016.

[7] Panduan Akademik, Universitas Negeri Padang, 2016.

[8] Purcell. Verberg. Rigdon, Kalkulus, Jakarta: Erlangga, 2010.

[9] Zainal Abidin, "Analisis Kesalahan Mahasiswa Mahasiswa prodi pendidikan Matematika Fahultas Tarbiyah IAIN-Raniry Dalam Mata Kuliah Trigonometri dan Kalkulus 1", Jurnal Ilmiah DIDAKTIKA, Agustus 2012, Vol XIII No.I, 183-196, 2012. 